University of Nebraska - Lincoln

DigitalCommons@University of Nebraska - Lincoln

Textile Society of America Symposium

Proceedings

Textile Society of America

2020

\title{
The State of Traditional Albanian Kilims, their Motifs and Narratives
}

Alexis Zoto

University of Southern California, alexis.zoto@usc.edu

Follow this and additional works at: https://digitalcommons.unl.edu/tsaconf

Digitart of the Art and Materials Conservation Commons, Art Practice Commons, Fashion Design Commens, Fiber, Textile, and Weaving Arts Commons, Fine Arts Commons, and the Museum Studies Netwerkns

Logo

Zoto, Alexis, "The State of Traditional Albanian Kilims, their Motifs and Narratives" (2020). Textile Society of America Symposium Proceedings. 1189.

https://digitalcommons.unl.edu/tsaconf/1189

This Article is brought to you for free and open access by the Textile Society of America at DigitalCommons@University of Nebraska - Lincoln. It has been accepted for inclusion in Textile Society of America Symposium Proceedings by an authorized administrator of DigitalCommons@University of Nebraska - Lincoln. 
Published in Hidden Stories/Human Lives: Proceedings of the Textile Society of America 17th Biennial Symposium, October 15-17, 2020. https://digitalcommons.unl.edu/tsaconf/ Copyright @ 2020 Alexis Zoto

doi: $10.32873 /$ unl.dc.tsasp. 0130

\section{The State of Traditional Albanian Kilims, their Motifs and Narratives}

Alexis Zoto

alexis.zoto@usc.edu

\section{Introduction and Objective}

After becoming aware of Rrok Zojzi's 1968 book Qilima Shqiptar a few years ago, my intention was to come to Albania, and document the meanings and narratives of the motifs and colors of Albanian kilims. Other countries in the region have documented this art form, most notably Turkey but also Serbia, Romania and Bulgaria.

I hoped to learn the meanings of these symbols and colors so that I can use these symbols in my practice as a fine artist. Also I wanted to understand why my Albanian Christian Orthodox great grandmother had a kilim with 'mosque' symbols all over it. I hope now to provide a baseline of information to be built upon both for developing kilim markets in Albania and for additional scholarly work. I traveled extensively in the country on weekends while during the work week I was in the Albanian National Archives in Tirana.

I am impressed by, aware of and grateful for, the work being done by scholars like Dr Nebi Bardhoshi, Dr. Olsi Lelaj, and Dr. Armanda Hysa to examine, deconstruct, analyze and recover ethnological information collected under the dictatorship. Their critique and articulation of the problems that occurred in academia during the Communist regime have helped me acquire a broader understanding of the context in which the Albanian National collection was made. It is all the more pressing to recover information, document Albanian culture, and help younger generations rediscover their heritage and identity.

\section{$\underline{\text { Brief Historical Context }}$}

Located in Southeastern Europe, Albania is a mountainous country about the size of the American state of Maryland. It has been an independent country since November 28, 1912 when it broke from the Ottoman Empire. By 1928 it was a monarchy. During WWII, Albania was occupied by fascist Italy and Nazi Germany. In 1944 the Nazis were out and Enever Hoxha established a Communist government. For almost 50 years Albania was an isolated and extreme police state. Communism fell in 1990. In 1997 Albania experienced civil unrest that some in Albania consider a civil war. It is now a developing economy and has a parliamentary form of government. Albania has a population of just under three million. Albania is a secular country, but the population has a majority of Sunni Muslim people with Shia minority Bektashi and a Christian minority which is Catholic and Orthodox. It is also important to note Albania has not had a 'truth and reconciliation process' yet.

\section{Methodology Context and Introduction}

In attempting to collect and understand information for my artistic practice, my research and analysis is not based on field literature, but as an artist. Searching for information on Albanian kilims is difficult because there is nothing much to find written on the subject. Scholarship on 
kilims in general is a strange and frustrating space between art history and connoisseurship. Most information available has odd hierarchies of aesthetics and provenance which seek to cater to dealers and collectors. Analyses of these kilims and rugs seem to be market driven. It is also striking that these domestic objects made by women are mostly discussed, written about and analyzed by men. As a result, I have used some very basic ethnographic and archival research approaches to this subject.

The research took place in the summer of 2018 at the Republika e Shqipërisë Akademia e Studimeve Albanologjike Instituti i Antropologjisë Kulturore dhe Studimit të Artit Departamentit të Etnologjisë (Republic of Albania Academy of Albanological Studies Institute of Cultural Anthropology and Art Study Department of Ethnology). The research was conducted using primary and secondary sources, such as interviews with weavers and experts, and the examination of traditional kilims and other woven textiles in the National Archives as well as studying photographs from the Marubi National Museum of Photography Archive. The textiles in the National Archive had not been looked at by foreigners, according to staff at the Archives.

\section{Methodology at the Albanian National Archives}

The Archive, according the staff, was created when Albania became an independent and recognized country in 1913 after being part of the Ottoman Empire. I worked in the Arkivi Tekstile-Lesh (Textile-Wool Archive) and was set to only look at kilims. Kilims, as defined by Professor Emeritus Dr Aferdita Onuzi (former director of the Institute of Cultural Anthropology and Art Studies), are flat woven rugs that have at least two borders. The kilims in the Archives are not stored in an archival manner at the moment. They are folded, one on top of another, on shelves in two closets. One closet is for the 'North' and one for the 'South'. I was asked to sit at a computer to look at digital images of the collection. Once that work was finished, I could pick a piece to look at in person. This was a surprise because when I visited the archives two years prior, in May 2016, these items were not yet photographed. The way the kilims are documented is problematic. The kilims are not depicted unfolded, flat, filling the frame. Instead, the kilims are photographed at an angle with perhaps one quarter of the kilim in the frame. The exposure and lighting are not consistent nor is there a color reference. There are no notes on the condition of the kilim. In addition, the kilims are mixed with other woven wool items like carpets, blankets and cradle covers.

The registry is handwritten in many decaying volumes. It only has the following information about each image: the date an item was entered into the registry, what the item is, what place it is from, and a brief descriptions that was inconsistent throughout the registry. There is little to no information on how old the object is, the size of the object, the item's provenance or anything related to the item's history. Some of the descriptive words in the registry are unknown, perhaps in an older dialect or a different cultural realm. When asked how these items were acquired, the staff said they were mostly donated or acquired on expeditions by Albanian Ethnographic specialists. When pressed for more information, the same answer was insisted upon. Photography of the kilims was not permitted and publishing any of their photos was not allowed. As a result, I sketched and made notes on each digital image in the collection. During my work with the registrar I spoke English, assisted by a translator. 


\section{Methodology for the Interviews}

Using a translator, appointments were made to interview professional weavers in their place of business or atelier in different regions of the country. There were a set of questions that started a conversation. Notes were taken. Because of Albania's traumatic recent history, I was advised by friends, family and colleagues to not tape weavers. However, I was traveling with a journalist from an Albanian television news organization who occasionally filmed me talking to the weavers.

Questions like the following were a starting point but ranged widely depending upon what the informant shared: When did you start weaving? Who taught you to weave? Where do you get your materials? How do you choose colors/designs? I also took my sketchbook and showed the weavers sketches of motifs from observations at the Archives. I asked each weaver if she recognized symbols, what was the name of the symbol and which symbols she used in their work.

\begin{tabular}{|c|c|c|c|c|}
\hline $\begin{array}{l}\text { name of } \\
\text { professional } \\
\text { weaver }\end{array}$ & retired & location & $\begin{array}{l}\text { age at the time } \\
\text { of the interview }\end{array}$ & $\begin{array}{l}\text { was employed } \\
\text { by a factory } \\
\text { during the } \\
\text { dictatorship }\end{array}$ \\
\hline Flutura Mata & & Kukës & 60’s & $\mathrm{x}$ \\
\hline Nebie Qotaj & & Zogaj & 60’s & $\mathrm{x}$ \\
\hline Tereze Gega & & Lezhë & 60 's & \\
\hline Shyqyri Kasmi & & Krujë & early 70's & $\mathrm{x}$ \\
\hline Diturie Rusta & & Korçë & 57 & \\
\hline Betie Nurçe & $\mathrm{x}$ & Korçë & 85 & $\mathrm{x}$ \\
\hline Merita Nurçe & & Korçë & 58 & \\
\hline Flora Cenko & & Korçë & 70 's & $\mathrm{x}$ \\
\hline Saide Gjeçi & $\mathrm{x}$ & Kavajë & 75 & $\mathrm{x}$ \\
\hline Mirela Danaj & & Antingonë & 48 & \\
\hline Alketa Skëndaj & & Antingonë & 45 & \\
\hline Vojsava Muho & & Antingonë & 48 & \\
\hline Ruhie Bineri & & Gjirokastër & 75 & $\mathrm{x}$ \\
\hline
\end{tabular}


Additional sources were with the following professionals: Professor Najada Hamza, textile specialist of the University of Tirana, private collector Gjon Dukgilaj, historian Ndoc Shaben, Professor Emeritus and author Jaho Brahaj, painter and designer Fatmir Vathi and painter and designer Muhamet Malilaj, journalist Ben Andoni, Jonathan Eaton of Cultural Heritage without Borders, Sadi Petrela and Lubjana Baoja both part of the GjiroArt organization and Gjirokastra Conservation and Development Organisation, painter designer and traditional clothing expert Stavri Qati, private xhubleta collector Luljeta Dano, and Professor Perparim Kabo of the the Mediterranean University of Albania.

\section{Findings from the Archival Research}

In examining the collection in the Archives I started with 'qilima' (kilims) and then included the 'sixhadë' (a rug with a pile) woven crib covers and the 'valenc' or 'lavenc' which is a heavy woven and felted wool blanket. It is important to note in the course of research I discovered other spellings of this blanket in Albanian, however I am using the spellings that were in the registry at the Archive. All of these textiles are produced on the loom. I have notes and sketches on a total of 152 textiles. The Archive started collecting objects when Albania became an independent country in 1913. In working with the registrar, we looked at each kilim, the description of which is usually limited to colors of the kilim, its border color, and shapes ie. a rhombus. There is mostly no identification of motifs other than noting there are 'geometric' motifs. On occasion, but not consistently, a motif or symbol is identified ie: 'xhamine' (mosque) or 'rrota' (wagon wheel). Another striking feature of the collection is the lack of pieces with representational imagery. There are only a few examples from southern Albania, one kilim from Tepelenë had abstracted/simplified figures in the border. Only two pieces that are woven on a loom but not kilims, have representational imagery. A pillow from Gjirokastër has two men on horseback with swords drawn facing each other; the other piece is also a pillow from Korçë with men and women, arms outstretched. In the national collection there is no information on how old the objects are, only the date of when they came to the registrar. There is also very little if any information on the provenance of these objects. When the registrar was asked about how these kilims were acquired, she said that they were either donated or purchased by an ethnographic team out in the field. Lastly, the collection does not cover all regions of Albania.

Here is the breakdown of places where the kilims came from:

\begin{tabular}{|l|c|}
\hline Name of town or region & Number of kilims in the collection \\
\hline Berat & 1 \\
\hline Dropull & 1 \\
\hline Gjirokastër & 3 \\
\hline Korçë & 57 \\
\hline
\end{tabular}




\begin{tabular}{|l|c|}
\hline Kosovo & 19 \\
\hline Kukës (including Shishtavec and Has) & 9 \\
\hline Leshnic & 1 \\
\hline Lumë & 1 \\
\hline Mamurras & 6 \\
\hline Migjeni & 5 \\
\hline Shkodër & 4 \\
\hline Tepelenë & 10 \\
\hline Tirana & 6 \\
\hline Vlora & 6 \\
\hline
\end{tabular}

There was no answer as to why there are so many more items are from Korçë than anywhere else or why other villages and towns are not at all represented. Also there was no answer as to why Shishtavec and Has are conflated into Kukës, other than they are in the same region. Because I was not able to physically examine each one of these textiles, I do not know how intact they are. I was able to touch and look at a few and then had to wash my hands immediately because the kilims had been treated with some kind of chemical pesticide. Another item of note was the presence of three Chinese rugs or Chinese style rugs in the collection. The registrar had no information on these rugs.

The context of this archive is striking in that most of the collecting was done during the Communist dictatorship. This immediately puts many questions forward such as, who decided what was accepted or not accepted in this collection? What role did the dogma of the regime play in the acquiring of objects? The dictatorship most decidedly affected the study of ethnography in Albania ${ }^{1}$. There have been numerous articles written to try to understand these problems ${ }^{2}$. (see Hysa) (see Lelaj) Some of this information may not be recoverable. I also believe there are handmade kilims in the collection that were made in factories for export and/or for tourists. In fact, there was an astounding amount of weaving that was done under the Communist regime.

\footnotetext{
${ }^{1}$ Aleksander and Chris Hann Bošković, ed. The Anthropological Field on the Margins of Europe, 1945-1991 LIT Verlag (December 31, 2013).

${ }^{2}$ Armanda Hysa, "Ethnography in Communist Albania: Nationalist Discourse and Relations with History," Historični seminar 8 , 2010, 103-124.

Lelaj, Olsi. "Lets Talk about "Communism"! Notes on politics, knowledge production and ethics in contemporary Albanian" Rivista di Scienze Sociali, 30 Agosto 2016.
} 
Hoxha's Albania had many factories employing thousands of women to weave kilims mostly for export. This brings us to the weavers interviewed.

\section{Findings from the Interviews}

Under Communism there were many factories producing handmade kilims and rugs mostly for export. This large system employed thousands of women. Instead of a handicraft being passed down matrilineally from one generation to the next, thousands of women were trained by the state and then worked in factories across Albania. A designer/painter, usually a man, then created designs for the women to produce. The men I interviewed self-identified as painters. These designers/painters were trained in the capital, Tirana, where designs were decided upon.

Factories like the one that existed in Krujë had approximately one thousand women making kilims for export and a couple of hundred for domestic consumption. Weavers told me that if they didn't finish, they would not get paid for their work; so they would often work all day and all night to meet a deadline or quota. They also shared that they were not allowed to talk to one another nor any visitor to the factory. The kilim and carpet factories no longer exist.

Many of the women I interviewed worked in those factories. Most of the women I spoke with said their craft is dying. They all mostly used wool that was chemically dyed or acrylic yarn. All the weavers were struggling financially. Many of the weavers said that weaving is their only source of income and many wished they could retire but don't have enough money or a pension in order to do so.

In Kukës, the interviewee Flutura Mata seemed to be in better shape than most. As I was told, because she has some support by the government, she is able to have additional weavers in her atelier. The reason (at that time) she has support is because her mayor is in the same political party as the president and the prime minister. Many other weavers did not enjoy such support. Almost all of the weavers I interviewed, including 75 and 85 year old women, learned to weave as young women in school and then went on to work in a factory. This means that these women weaved by hand with sometimes one thousand other women in a factory. Some of these factories had one thousand women weaving kilims for export, three hundred women making sixhadë (a rug with pile) and another one hundred weaving for their fellow Albanians. These numbers are based on what informant Vatmir Vathi said. He was the head designer for a factory in Krujë. He would go to the capital and there it would be decided what designs and colors would be made in which factories. While all the weavers I talked to seemed to love their craft, when it came to discussing meanings of the imagery used the conversation started to get vague. It was as if the ancient meanings of these symbols that they used had been obscured, erased or simplified.

The interviewee Nebie Qotaj in Zogaj was an outlier. She learned to weave from her mother when she was a young girl. Weaving traditionally is a craft passed down matrilineally in many countries of the former Ottoman Empire. Nebie knows how to prepare the wool and make natural dyes from local plants. When I asked her about symbols, Nebie said she always used traditional designs. She kept referring to a catalog of symbols. When I asked to see what she was talking about, she showed me 'Arti Popullor Shqiptar: Punime Leshi ne Vegje' (Albanian People's Art: Woolen Objects Woven on the Loom) published in 1977. This was her source for symbols and designs that she faithfully reproduced. There is no information in this book about the meanings 
of the symbols. She referred to this book because everything in it is 'traditional.' Communist era published material was and is the source for imagery for all the women I spoke with.

Korçë was, before Communism, a big producer and exporter of kilims. As a result, the kilims from Korçë were known to be more 'professional' and 'exact' compared to other regions of Albania. I visited the site of an old factory there and across the street was the wool processing factory both of which still are operating on a much smaller scale. One of the oldest weavers I interviewed, Betie Nuçe in Korçë, talked about changing symbols to make them 'more beautiful' and making kilims in the Kosovar style. She talked about looking at old Egyptian and old Turkish designs. She also said there was once a small evil eye symbol in use but you could only see it on very old kilims if at all. As we talked, she mentioned that her mother was from a wealthy family and never knew hard labor. She said during the worst years of Communism she lived in one room with four kids and her husband. They were all very hungry. Now her daughter is an epidemiologist and loves handicrafts and weaving.

Saide Gjeçi of Kavajë started as a weaver and then went on to train women in weaving. She shared a lot of information about the factory system. Designs came from Tirana and then the women had to work out dimensions for scaling the design to the size of the rug. She said there were factories in Kavajë, Krujë, Tirana and Skijak. (According to designer/painter Stavri Qati, there were twelve factories in all of Albania.) She also said they made portraits of Lenin and Hoxha. In fact a kilim with a portrait of Lenin was given as a gift to Khrushchev when he visited Albania. She said they were all shocked when he accepted the gift, folded it and sat on it. She said that they wanted to laugh but were too scared and didn't show any reaction.

GjiroArt is a handicrafts collective in the UNESCO world heritage designated town of Gjirokastër. In the 'old bazaar' Ruhie Bineri, a 75 year old weaver, has a little store front. She too is from the factory system. Weavers in the nearby town of Antigonea were some of the youngest women I interviewed. They are all in their forties. Vojsava Muho was taught to weave by her mother and so was Alketa Skëndaj.

Mirela Danaj's mother-in-law taught her. This group of weavers works as the collective 'Artizanet e Antigonese' with a total of ten women doing handicrafts. In addition to trying to make traditional kilims and handicrafts, they wove scrap fabrics, made pom-poms and other knitted pieces. This collective was the only group of professional weavers who had members that had not worked in the factory system.

\section{Discussion of Symbols}

Visiting bazaars and weavers' studios, I was struck by the uniformity of compositions currently being made. There was scant knowledge of what design hallmarks belonged to what region. Weavers' desire to be faithful to 'traditional' Albanian kilim designs is admirable, however it is completely informed by Communist era information. Designs made during the old factory days are still in use. In the weaver collective in Antigonea, the weavers are still asking painter designer Stavri Qati to create designs for them. Weavers in the southern region of Albania recognize and make designs that are from the northern region of Albania, the Kukës region. However, I did not observe the reverse; weavers in the north using designs from the southern 
region.

Weavers had varying responses to questions about the symbols. One said she was not educated and I don't know. Another said the symbols are traditional. Another asked why a symbol has to have a meaning at all. Some weavers were able to identify some symbols. However, they all were more concerned with getting orders and fabricating what was asked of them. Diturie Rusta talked about an order that perplexed her. She was asked to weave a traditional Korçë kilim with the 'hapur dhe mbyllur' or 'open and closed' motif, but in green and blue - colors that were not traditionally used with that design. Traditionally, it is composed of red designs on a black or dark blue field or vice versa. There are examples of this in the Albanian National Archives collection. The 'bukë' (bread) motif and/or 'galetë' (biscuit) motif present in Rrok Zojzi's book are also recognized by many weavers in Korçë.

The 'xhamine e madhe' (large/great mosque) or 'xhamine e vogële' (small mosque) symbol seems to mostly appear in the Korçë region and some towns in the South along with the 'hapur dhe mbyllur' or 'open and closed' symbol and the 'bretkocë' (frog) motif. In discussing the 'mosque' symbol many informants did not recognize the symbol outside of Korçë. Informants in Korçë talked about how in the old days Orthodox women made the best kilims with the mosque symbol. One informant talked about it being an expression of brotherhood between the religions. Many of the 'mosque' symbols have another symbol inside, some look like a vase or water jug, others look more zoomorphic like a chicken, rooster or bird. One of the zoomorphic symbol was identified as a horse by informant Merita Nurçe. She said it was for the 'old horse mosque'. I wasn't able to find an old mosque called 'kalë'(horse). The figure seems to resemble a hoopoe. A bird common to the region and is used in textiles in Egypt and in neighboring countries. Some weavers were not so sure about identifying symbols. Other informants talked about the 'mosque' symbol originally being a house or a 'tree of life'. The last iteration of the mosque motif I came across had what looked to me like a vine or tree of life motif sometimes with a Greek cross at the top. When I asked informants about this configuration, they said maybe it was a church. One informant identified this as a chandelier inside the mosque.

What is identified as the 'mosque' symbol in Albania is well known and used throughout the region. In Serbia the symbol is identified as 'mirab' and mirror. However the word 'mirab' or 'mihrab' is an Arabic word. Mihrab is a semicircular niche in the wall of a mosque that indicates the qibla; that is, the direction of the Kaaba in Mecca and hence the direction that Muslims should face when praying. The symbol can also be singular, in the centre of the kilim and is sometimes recognized as a prayer rug. This design of the prayer rug is easily found in neighboring countries like Bulgaria and Turkey. I saw at least one example in the Albanian National Archives however it was not identified as a prayer rug.

In the northern part of Albania, particularly Shkodër and Kukës, many different symbols were identified as 'double headed eagle'. The double headed eagle is on the Albanian flag and part of Albanian national identity. Some informants identified too many (it seemed to me as odd and almost pathological) symbols as the double headed eagle.

Why are so many different symbols identified as the national symbol of Albania? Because there were so many examples, were these all symbols of resistance? Or were they something else but 
due to a nationalistic and atheist culture they all became double headed eagles? Many people I talked to seemed to have a very hard time with this line of questioning. Some people seemed resistant and offended by my questions. There is a book on the history and use of the double headed eagle in Albanian culture by Jaho Brahaj but it is written in Albanian.

Other symbols were identified as stars, birds, butterflies, and flowers. I did ask if there were any symbols for protection or fertility and unanimously the weavers said no. One or two of them talked about symbols on traditional clothing. Symbols and motifs in traditional clothing seems to be better known but not necessarily better documented. Its is likely there would be relationships between the motifs in these different textiles but that work has not been done yet.

\section{$\underline{\text { A Few Words About Color }}$}

Albania is best known for using red and black, the colors of the national flag. There are some regional differences but more work needs to be done in this area. The Northern part of Albania is known for its distinctive palette that usually includes a particularly bright pink. The Southern part of Albania has many kilims that are two colors, red and blue or red and black. There also seems to be an absence of pink although I did see a 'valenc' with pink in the Archive from Korçë. Many people shared with me the idea that the Northern region of Albania is more 'pure' and authentic than the southern part. Their reasoning is that the region was more isolated. They also said the southern part was too influenced by Greece and Greek culture. I don't know if this is true, but I found this assertion very strange given what I know about Albania's history, occupiers and changing borders over time. Some of the scholarly Albanians who asserted this idea were from the North themselves, and I don't know if that had something to do with their belief. One Austrian scholar shared her idea that there is nothing authentic at all about the kilims because the kilims came with the Ottomans.

Dr. Aferdita Onuzi shared a paper ${ }^{3}$ with me that has some information on traditional dyes. According to Dr. Onuzi, there was not a tradition of indigo growing and dyeing. More work needs to be done researching dyes and color palettes. It is clear from looking at the archive aniline dyes have been present in Albania for a long time.

\section{$\underline{\text { In Closing }}$}

My work in Albania has created more questions than it has provided answers. I see this work as a status report and baseline to build upon. Many have disregarded Albanian kilims, saying that they are not original, or they are Turkish. It is true that Albania was part of the Ottoman empire for hundreds of years. Dr. Onuzi herself said kilims were imported from Turkey. However it stands to reason that if Albanians were able to hold onto their language for hundreds of years, their unique traditions would be evident in their material culture and weaving.

Sadly, it was not possible to reach the heart of this tradition in the weeks I was in Albania. Focussing on professional weavers shows the extent of the factory system's historical dominance on this craft. Folk art and folk tradition for some generations of Albanians are a painful reminder

\footnotetext{
${ }^{3}$ Aferdita Onuzi, “Përdorimi i Ngjyrosësve Natyrorë dhe Kimikë në Tekstilet tona Popullore,” Gjurmime Albanologjike Folklor dhe Ethnologji, (1998-1999), 28-29.
} 
of the dictatorship. Many people felt as if folk traditions were shoved down their throats. Perhaps there was a disconnect between the authentic and what was used for propaganda and nationalist narratives of the dictatorship. As a result, many of the regional hallmarks and styles were completely confused or conflated. Now there are gaps of awareness and understanding of weaving and folk-culture in different generations of Albanians.

This research raises the following next steps and questions: what can be discovered in Albanian diaspora communities? Are there Albanian kilims or historical material about Albanian kilims in other museums and collections outside of Albania? What do home weavers in Albania know about symbols and motifs? What sorts of kilims and carpets are made in regions not covered in this research as well as what is in the archive? How does Albanian weaving compare with its neighbors?

Kilims were a practical domestic item historically present in every Albanian household, rich or poor. Traditionally kilims were for brides. Kilims had multiple functions. There were special kilims for the guest room of a traditional house, and kilims that were cradle covers. They were an essential part of the 'pajë' (trousseau). Young women either made them for themselves with help from other female family members, or if they were from a wealthy family, they would purchase them. Preparing the wool, spinning it and dyeing it was laborious. Weaving is also very physical work. Yet many women designed and made these useful everyday objects.

It is amazing to think about the brilliance of women who not only prepared their own wool and spun it, but also knew the chemistry to make dyes using plants, insects, ash, and animal urine. They memorized designs and motifs to create kilims without graph paper. In many places designs and motifs in kilims came from the natural world as well as the artisan's humanity and aspirations. Dr. Onuzi mentioned in one of our conversations that there is a song where the woman sings 'I am writing a kilim...I am writing a border of a kilim'. In many cultures kilims are thought to tell a story. In Albania, it seems, many of these stories are obscured, misplaced or lost.

\section{Bibliography}

Abazi, Enika and Albert Doja. "From the communist point of view: Cultural hegemony and folkloric manipulation in Albanian studies under socialism" Communist and Post-Communist Studies, Elsevier, 2016, 49 (2),163-178.

Andoni, Ben, Personal Interview, June 6, 2018.

Bihiku, Ikbale, and Instituti i Historisë (Akademia e Shkencave e RPS të Shqipërisë). Sektori i Etnografisë. Arti Popullor Shqiptar: Punime Leshi ne Vegje, Published by Shtëpia Botuese "8 Nëntori” Tirana, 1977.

Bineri, Ruhie, Personal Interview, June 9, 2018. 
Bošković, Aleksander and Chris Hann ed. The Anthropological Field on the Margins of Europe, 1945-1991, LIT Verlag (December 31, 2013)

Brahaj, Jaho, Personal Interview, May 31, 2018.

Cenko, Flora, Personal Interview, May 27, 2018.

Danaj, Mirela, Personal Interview, June 10, 2018.

Dano, Luljeta Personal Interview, June 4, 2018.

Dukgilaj, Gjon, Personal Interview, May 19, 2018.

Gega, Tereze, Personal Interview, May 12, 2018.

Gjeçi, Saide, Personal Interview, June 9, 2018.

Hysa, Armanda. "Ethnography in Communist Albania: Nationalist Discourse and Relations with History" Historični seminar 8, 2010, 103-124.

Kabo, Perparim, Personal Interview, June 6, 2018.

Kasmi, Behare and Shyqyri, Personal Interview, May 13, 2018.

Krody, Sumru Belger. “The Power of Color: Anatolian Kilims” DigitalCommons@University of Nebraska - Lincoln, Textile Society of America Symposium Proceedings, 2016.

Lelaj, Olsi. "Lets Talk about "Communism"! Notes on politics, knowledge production and ethics in contemporary Albanian" Rivista di Scienze Sociali, 30 Agosto 2016.

Malilaj, Muhamet, Personal Interview, June 2, 2018.

Marash, Tatiana, Personal Interview, May 26, 2018.

Mata, Flutura, Personal Interview, May 19, 2018.

Muho, Vojasava, Personal Interview, June 10, 2018.

Nurçe, Betie and Merita, Personal Interview, May 26, 2018.

Onuzi, Aferdita, Personal Interview, May 10, 2018.

Onuzi, Aferdita, Personal Interview, May 18, 2018. 
Onuzi, Aferdita,. "Përdorimi i Ngjyrosësve Natyrorë dhe Kimikë në Tekstilet tona Popullore" Gjurmime Albanologjike Folklor dhe Ethnologji, 28-29, 1998-1999.

The Oxford College Dictionary, second edition, Oxford University Press, Inc. and Spark Publishing, NY, 2007.

Qati, Stavri, Personal Interview, June 9, 2018.

Qotaj, Nebie, Personal Interview, May 20, 2018.

Petsopoulos, Yanni, One Hundred Kilims: Masterpieces from Anatolia, Alexandria Press LTD, London, 1991.

Rusta, Diturie. Personal Interview, May 26, 2018.

Shaben, Ndoc, Personal Interview, May 20, 2018.

Skëndaj, Alketa, Personal Interview, June 10, 2018.

Vathi, Fatmir, Personal Interview, May 31, 2018.

Zojzi, Rrok, Qilima Shqiptare, Published by Albania State University of Tirana, Tirana,1960.

Acknowledgments and Funding: This paper was made possible by the University of Southern California Zumberge Individual Innovation Grant. Also this project would not have been possible without the following people: Albina and Bujar Kore, Prof. Najada Hamsa, Migena Dukagjini, Thom and Françeska Therçaj, Dr. Nebi Bardhoshi, Valerie Kerxhalli, Vrisidha Zoto, and Lisavetta Lalaj. 